\title{
Green biosynthesized Satureja rechingeri Jamzad-Ag/poly vinyl alcohol film: quality improvement of Oncorhynchus mykiss fillet during refrigerated storage
}

\author{
Elham KAVAKEBI ${ }^{1 \varsigma}$, Amir Ali ANVAR ${ }^{1 *}$ (D), Hamed AHARI ${ }^{2 \varsigma}$, Abbas Ali MOTALEBI ${ }^{1}$
}

\begin{abstract}
The nanosilver food packaging films were developed by polyvinyl alcohol activated with Satureja rechingeri extract (S-AgNPs/PVA) using the solvent casting to evaluate the freshness of Oncorhynchus mykiss fillets during 14 days at the refrigerated temperature. The 160 pieces of fish were enfolded in 4 types of films as main group-series. The main components of the extract were carvacrol $(83.2 \%)$ p-cymene (3.11\%), thymol (2.13\%) and $\gamma$-terpinene (1.63\%). The UV-Vis and TEM evaluations of S-AgNPs showed that the size of S-AgNPs was mostly smaller than $55 \mathrm{~nm}$ in diameter. Mesophilic and psychrophilic bacteria counts were remarkably less than $6.0 \log \mathrm{CFU} / \mathrm{g}$ about 2.1, $1.3 \mathrm{log} \mathrm{CFU} / \mathrm{g}$ and 2.0, $1.0 \mathrm{log} \mathrm{CFU} / \mathrm{g}$, respectively for fish samples wrapped in S-AgNP/Ult.PVA (Ultrasound method) and S-AgNP/Pho.PVA (Photochemical method) preserved at $4{ }^{\circ} \mathrm{C}$ on the 7 th day. S-AgNP/Ult.PVA and S-AgNP/Pho.PVA showed strong efficiency in complete eliminating S. aureus and psychrophilic bacteria from coated trout samples than E. coli and mesophiles. It is suggested that AgNP/Ult.PVA and S-AgNP/Pho.PVA films can be used as nanocomposite film for fish preservation at refrigerated temperature to postpone the spoilage up to 7 th day.
\end{abstract}

Keywords: green biosynthesis; Satureja rechingeri; nanocomposite; polyvinyl alcohol; fish; shelf life.

Practical Application: Films produced from Polyvinyl alcohol activated with Satureja rechingeri extract (both Photochemical and Ultrasound methods) and silver nano-particles can be applied as nanocomposite films in food-packaging industries to extend shelf life of fish fillets preserved at refrigerated temperature.

\section{Introduction}

The nanotechnology is extensively applying in the medicine and industries. The use of nanocombinations plays a crucial role in maintaining freshness and original nutritional attributes in food (Anvar et al., 2019). Metallic nanoparticles (MNPs) which have the antimicrobial potential can be applied in retaining the agricultural products such as fish, chicken, etc. (Lotfi et al., 2019). The biopolymers can be simply pooled with MNPs to produce the green combinations (Logeswari et al., 2015) to extend shelf-life of products, while they contact the products in the packaging (Santos et al., 2020; Singh \& Danai, 2019). Among these products, the fish have a high degree of perishability; however, they specifically prone to rapid microbial spoilage, while they maintain high the freezing point $\left(0.0^{\circ} \mathrm{C}\right)$. At this circumstance, the fish carcass is not frozen, bacterial and enzymatic activities have increased, and affectedly shortened the shelf life (Paladini et al., 2019). To extend the shelf-life, fish should be kept under appropriate condition, in which the growth of bacterial spoilage is prohibited. natural compounds such as gelatin, and green nanocomposites are used to inhibit spoilage activities of bacteria (Wei et al., 2019). Nanocomposites are fabricated with silver nanoparticles/lowdensity polyethylene (AgNPs/LDPE) which can increase the shelf-life of fish at refrigerator temperature (Anvar et al., 2019), but for a limited storage time. Thus, prolonging the storage time for fresh fish preservation is a critical measure in the processing (Zulkarneev et al., 2019). Due to some evidence over the silver escaping from nanocomposite and worries concerning the recycling of LDPE as a host for silver ion and biocompatibility; however, the researchers are interested in either the green-synthesis of nanocomposites by reducing the concentration of silver and other ions in the final products (Dehghanizade et al., 2018), which produced from natural substrates such as tea polyphenols and chitosan composite film (Peng et al., 2020), edible film from mammee apple, Mammea americana a well-known tropical fruit (Nascimento et al., 2020), starch based film loaded with Uncaria gambir (Santoso et al., 2019), yam/maize starch edible film with lemon plasticizer (Song et al., 2019) or the environment-friendly polymer-based compounds as a host for ions (Nwabor et al., 2020). The herbal-derived nanoparticles (NPs) such as Savory (S. rechingeri) extract with remarkable antimicrobial activities can be applied in various professions such as health care, food industries, biomedicine and engineering sciences. Savory which belongs to the Lamiaceae containing more than 200 species of herbs (Navarro-Rocha et al., 2020) is one of the herbal medicine specifically rises in many countries in the Mediterranean area (Nwabor et al., 2020) and west of Asia where Iranian people have it daily as a side food or edible vegetable. It is well-known that it has great antioxidant properties compared to many vegetables, even higher than that of quercetin (Souri et al., 2004). Its extract can be used as a hybrid accompanying with the polymers (Mathew et al., 2018). Polyvinyl alcohol as the biodegradable 
polymer is a non-toxic, water-soluble, and transparent alteration of LDPE (Demir et al., 2019; Reddy et al., 2019) and can be activated with other natural compounds such as cellulose nanoparticles . Also, they have the appropriate obstacle characters to gases such as oxygen and carbon dioxide making its nanocomposite well-matched for fresh fish-coating in the packaging.

In this study, PVA based nanocomposite blend film incorporated with Aqueous extract of $S$. rechingeri and AgNPs was fabricated by solvent casting method. The nanocomposite blends were further characterized. Antibacterial and quality attributes were assessed while the O. mykiss fillets were encased in a different type of S-AgNPs/PVA films at refrigerated temperature for 2 weeks.

\section{Materials and methods}

\subsection{Materials}

Solid AgNO3 as lab grade, glycerol solution $86-89 \%(\mathrm{~T})$, and PVA powder were prepared from Sigma-Aldrich (Germany).

\subsection{The preparation of extract}

The fresh Samples of S. rechingeri Jamzad (Savory) included leaves and flowers which their aerial parts were $100 \mathrm{~g}$ purchased from the grocery market, cut into small pieces, chopped, dried and put into a Clevenger glassware flask prefilled with $1.6 \mathrm{~L}$ of 2 times-ionized water (Pouya-Electric, Iran) and heated for $3 \mathrm{~h}$ at $80^{\circ} \mathrm{C}$. The ultimate extract with pale-yellow color was obtained and kept in the refrigerator to use.

\subsection{Gas Chromatography-Mass Spectrometry (GC/MS)}

The GC analysis was accomplished using PerkinElmer, Clarus 500 gas chromatograph, fixed with an HP 5MS $30 \mathrm{~m} \times 0.25 \mathrm{~mm} \times 0.25 \mu \mathrm{m}$ film thickness capillary column and flame ionization detector. The column's temperature was initiated at the set from $60^{\circ} \mathrm{C}$ and gradually increased to $280{ }^{\circ} \mathrm{C}$ at a rate of $3{ }^{\circ} \mathrm{C}$ a minute. The injector and detector temperatures were calibrated at 230 and $300{ }^{\circ} \mathrm{C}$, respectively. Helium as the transporter was deployed at a unit of $1 \mathrm{~mL} / \mathrm{min}$. GC/MS analyses were accomplished with a Hewlett-Packard 5973-6890 GC/MS system functioning on electrospray ionization mode. Furthermore, the determination for each combination was confirmed by the evaluation of available marker samples (Alsaraf et al., 2020).

\subsection{AgNPs synthesis}

The $0.001 \mathrm{M}$ silver nitrate $\left(\mathrm{AgNO}_{3}-\right.$ Merck, Germany) was combined with $S$. Rechingeri extract using two following procedures (Narchin et al., 2018):

1) Photochemical: $\mathrm{AgNO}_{3}$ reagent as a precursor for silver and the original extract of $S$. Rechingeri were combined with a ratio of 1:4 to synthesize the combination of S-AgNPs. The sample was kept under the daylight for $5 \mathrm{~min}$ at $\mathrm{pH}=7$. The rapid color alteration from light yellow to maroon implied making the AgNPs. Then, the samples were kept at room temperature for 24 hours;
2) Ultrasound: The previous proportioned combination for the initial phase of the photochemical process was introduced to ultrasound irradiation at $40 \mathrm{~Hz}$ in the dark condition for $30 \mathrm{~min}$ in triplicate at $40^{\circ} \mathrm{C}$ and $\mathrm{pH}=7$. The changes in color from light yellow to maroon implied making the AgNPs.

\subsection{Production of S-AgNPs/PVA films}

The compounds deployed in this study were of the methodical grade. The S-AgNPs/PVA film was fabricated with macerated $5 \%$ PVA (w/v) powder (Merck, Germany) in hot 2-times distilled water and agitated at $80^{\circ} \mathrm{C}$ for $1 \mathrm{~h}$ (Devi \& Umadevi, 2014). The ultimate obtained solution was left at room temperature to be cooled, and the bubbles disappeared. The S-AgNPs reagent produced by two afore-mentioned methods individually was dripping into the flask prefilled with $0.75 \%$ glycerol as plasticizer and PVA solution at $65{ }^{\circ} \mathrm{C}$ for 25 min with slow stirring until a brown adhesive solution was appeared implying on the synthesis of S-AgNPs/PVA colloid (Figure 1). The finalized films were fabricated by the casting method (Nwabor et al., 2020) on a Teflon plate (Nippon Fusso, Japan).

\subsection{Characteristic measurement}

The prepared Ag/S. rechingeri were characterized by UV-visible spectroscopy, transmission electron microscopy (TEM), and $\mathrm{X}$-ray diffraction (XRD). UV-visible spectroscopy is a crucial method applied to accept creating the metal nanoparticles in an aqueous solution. Therefore, producing the AgNPs was determined with scaling the UV-vis spectrum of reaction S-AgNPs. When the herbal extract became homogeneous in the solution of the $0.001 \mathrm{M}$ silver nitrate, the reduction of AgNO3 into AgNPs in contact with plant extract was measured with UV-Vis spectrum (Shimadzu, Osaka, Japan) nad the absorption spectrum was recorded, ranging from $300-800 \mathrm{~nm}$ (Alaraidh et al., 2014).

The crystal structure of the produced Ag-NPs was examined with analysis of X-ray diffraction (XRD) patterns obtained from a diffract meter system (PANalytical, XPERT-PRO) The XRD patterns were recorded at a scanning speed of $4 \% \mathrm{~min}$ (Jaiswal et al., 2020).

The scattering quality and size of S-AgNPs was examined using the Transmission electron microscopy (TEM) micrographs CM120 system from PHILIPS Co., Netherlands (Emamifar et al., 2010).

\subsection{Study design}

The whole live O. mykiss (15 kg) with an average body weight of $220 \pm 43.20 \mathrm{~g}$ were purchased from the fish market and transferred to the microbiological lab with a distance less than $1 \mathrm{~h}$, eviscerated, washed with cold water and cut in some pieces. The 160 pieces of fresh $O$. mykiss fillets with an average weight of $50 \pm 2.3 \mathrm{~g}$ were assigned to 4 groups (Table 1) based on a factorial design of three factors as $4 \times 2 \times 4$ (Types of extract included control containing Aqueous, S-AgNP/Ult.PVA and S-AgNP/Pho.PVA; the storage temperature of coated fish fillets at 4 and $8^{\circ} \mathrm{C}$ and finally sampling days of $1,3,7$ and 14 , respectively). The fish samples were enclosed in plasticized PVA stored in two 


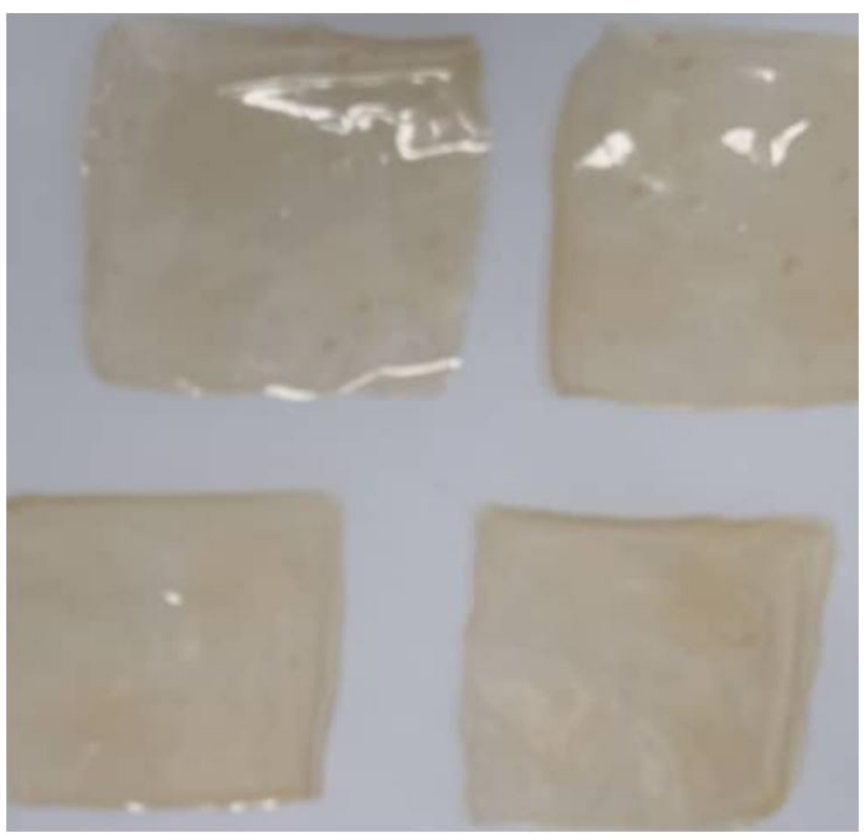

Figure 1. Ultimate produced Savory-Ag/Polyvinyl alcohol nanocomposites.

Table 1. The group assignment for experiment.

\begin{tabular}{|c|c|c|c|}
\hline Coating/Nano Production & Temp. ${ }^{\circ} \mathrm{C}$ & Days & Group N0. \\
\hline \multirow[t]{8}{*}{ Control } & 4 & 1 & $\mathrm{G} 1$ \\
\hline & & 3 & \\
\hline & & 7 & \\
\hline & & 14 & \\
\hline & 8 & 1 & G2 \\
\hline & & 3 & \\
\hline & & 7 & \\
\hline & & 14 & \\
\hline \multirow[t]{8}{*}{ S-Aqueous } & 4 & 0 & G3 \\
\hline & & 3 & \\
\hline & & 7 & \\
\hline & & 14 & \\
\hline & 8 & 1 & G4 \\
\hline & & 3 & \\
\hline & & 7 & \\
\hline & & 14 & \\
\hline \multirow[t]{8}{*}{ S-AgNP/Ultrasound } & 4 & 1 & G5 \\
\hline & & 3 & \\
\hline & & 7 & \\
\hline & & 14 & \\
\hline & 8 & 1 & G6 \\
\hline & & 3 & \\
\hline & & 7 & \\
\hline & & 14 & \\
\hline \multirow[t]{8}{*}{ S-AgNP/Photo chemical } & 4 & 1 & G7 \\
\hline & & 3 & \\
\hline & & 7 & \\
\hline & & 14 & \\
\hline & 8 & 1 & G8 \\
\hline & & 3 & \\
\hline & & 7 & \\
\hline & & 14 & \\
\hline
\end{tabular}

refrigerators, adjusting to 4 and $8{ }^{\circ} \mathrm{C}$ up to 14 days (Figure 2). The group-series S-AgNPs Ult.PVA and S-AgNPs/pho.PVA were named for the fish coated with S-AgNPs/PVA nanocomposite film fabricated through ultrasound (Ult.) and photochemical (Pho.) methods, respectively. In addition, S-Aqueous and control group were named for the group-series in which the fish samples were covered with S/PVA (excluding AgNPs) and PVA films (excluding S/AgNPs), respectively (Table 1).

\subsection{Bacterial analysis}

The $25 \mathrm{~g}$ of $O$. mykiss fillets were added to $225 \mathrm{~mL}$ of buffered peptone water $0.1 \%$ (Merck, Germany) and homogenized in a stomacher (lab blender 400, Italy) at $260 \mathrm{rpm}$ for 30s to obtain the colony-forming unit (CFU)/g for mesophilic bacteria count (MBC). Thereby, a ten-fold serial dilution was carried out in the peptone water, $1 \mathrm{~mL}$ of each dilution (initial suspension) pour plated with Plate Count Agar (PCA, Merck) in triplicate and finally incubated at $35^{\circ} \mathrm{C}$ for $48 \mathrm{~h}$ to count mesophilic bacteria.

Simultaneously, the psychrophilic bacteria count (PBC) was carried out. The $1 \mathrm{~mL}$ of final dilutions was added to the surface of triplicated plates pre-filled with Plate Count Agar (Sigma Aldrich, Germany) and incubated at $7{ }^{\circ} \mathrm{C}$ for 10 days (Ceylan et al., 2018).

The evaluation was continued with $E$. coli enumeration. The 3-tubes most probable number (MPN) method was applied to enumerate E. coli following Ramires et al. (2020) method with major modification. The serial dilutions of $10^{-1}-10^{-3}$ were made using the initial suspension. Three series of tubes ( 3 tubes) prefilled with $10 \mathrm{~mL}$ of Lauryl Sulfate Broth (Sigma-Aldrich, Germany) was used so that $1 \mathrm{~mL}$ of each dilution was added to the tube of each series and incubated at $37^{\circ} \mathrm{C}$ for $24-48 \mathrm{~h}$. Due to the instruction of manufacturer, Turbidity of broth and gas formation were the clues for the presence of $E$. coli and/or other coliform organisms. Consecutive incubation phases were completed (in order) with inoculated EC broth and Trypton water (Oxoid, UK) at $44^{\circ} \mathrm{C}$ for 24-48h, while the gas presence in Durham tubes was observed.

The biochemical test for Salmonella spp. growth was carried out with the incubation at $37^{\circ} \mathrm{C}$ for $18 \mathrm{~h}$ using Bismuth Sulfite Agar (BSA) and Xylose Lysine D xycholate (XLD) agar (SigmaAldrich-Germany).

All plates with colony-forming units between 30 and 300 were recorded. The plates containing values greater than 300 were counted with colony meter applying the method of Khoshbouy Lahidjani et al. (2020) with major modification. To enumerate quagulase-positive $S$. aureus, the $1 \mathrm{~mL}$ of final bacterial suspension was inoculated on the surface of Baird Parker agar (BPA Sigma Aldrich, Germany) which incubated at $37^{\circ} \mathrm{C}$ for $24-36 \mathrm{~h}$ (Sarab et al., 2019).

The CFU/g of bacteria were numerated following Equation 1.

$\mathrm{CFU} / \mathrm{g}=\frac{\Sigma \mathrm{c}}{\mathrm{V}[\mathrm{n} 1+(\mathrm{d} \times \mathrm{n} 2)] \times \mathrm{d}}$

when: $\Sigma c=$ Sum of the CFUs counted on plates of two consecutive dilutions; $\mathrm{V}=$ sample volume inoculated to each plate $(\mathrm{mL})$; 


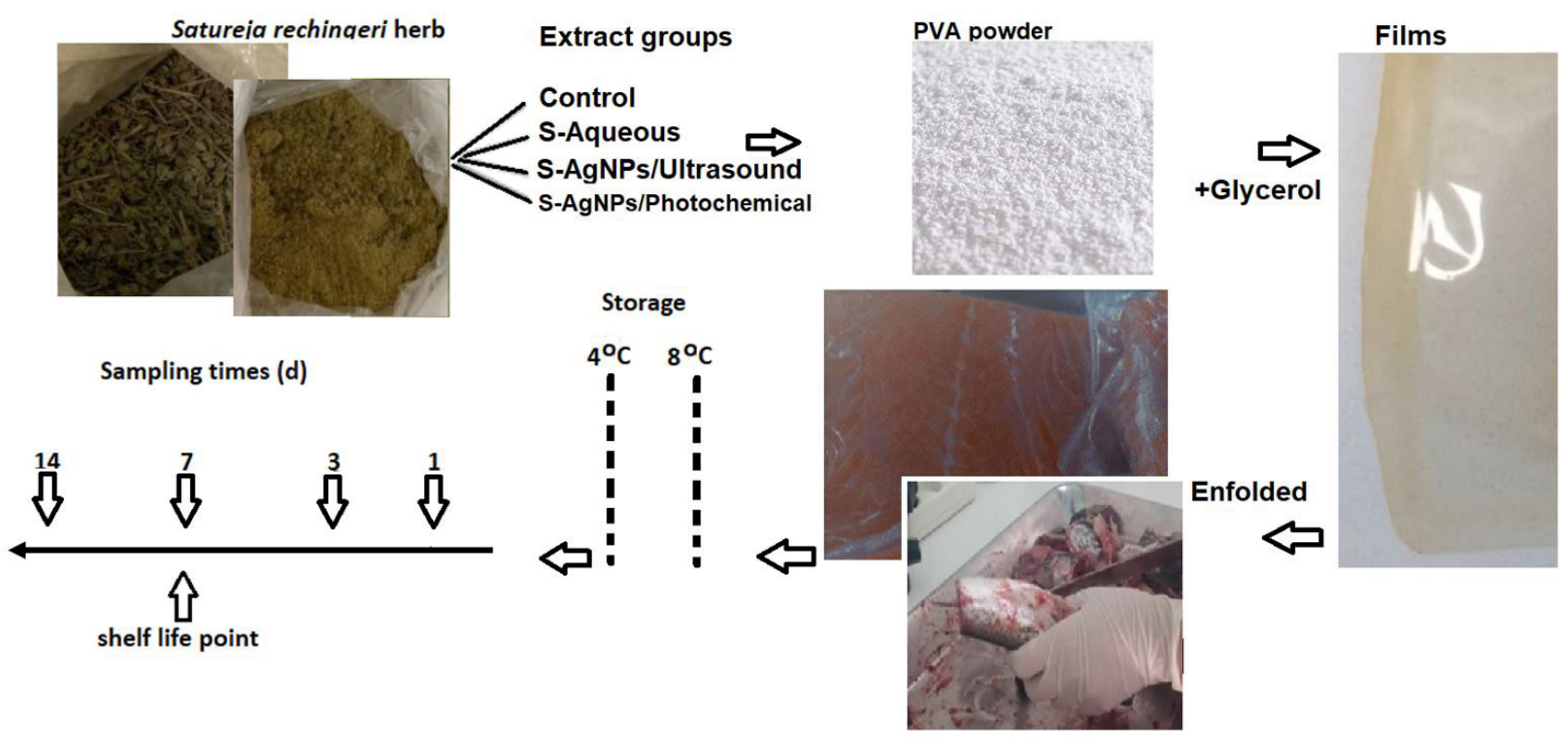

Figure 2. The Outline of experiment-the groups were controlled, Satureja rechingeri-Aqueous extract-PVA film, Satureja rechingeri-AgNPs/ Ultrasound-PVA film, and Satureja rechingeri-AgNPs/photochemical-PVA film. O. mykiss fillets were folded in different films, stored at different degrees of temperature, and sampled in various days.

$\mathrm{n} 1=$ number of the selective plates for the first dilution; $\mathrm{n} 2$ = number of the selective plates for the second dilution; $\mathrm{d}=$ dilution coefficient concerning the first selective dilution.

\subsection{Sensory assessment}

The sensory assessment was done using one or more of five senses to evaluate the quality of fish enfolded in a different type of plasticized PVA at the time of sampling using the method of Diler \& Genç (2018) with major modification. Trout samples were judged for appearance (skin brightness of fillets) color (fillet color changes), odor (sour, rotten), texture (fingermark disappeared immediately or within the time), and general acceptance (average score of main attributes). The 5-point hedonic technique was applied, and the fish samples were scored with values included 1 (excellent), 2 (good), 3 (acceptable), 4 (moderate) and 5 (weak), suggesting by panelists composed of 10 evaluators were trained following Nawaz et al. (2019).

\subsection{Statistical analyses}

Data of bacterial count were analyzed using a mixed model, ANOVA repeated measure-Mixed model. A factorial assignment was fixed to study the effect of 4 groups of the extract methods and two temperature of storage using 3 replicates. A Bonferroni test was carried out to compare the differences among the groups 2 by 2 . No any non-parametric alternative to ANOVA-repeated measurement was accessible to analyze the qualitative data of organoleptic criteria, however, two independent variables including extract methods and temperature converted to one variable (Extract-Temperature) using compute approach in SPPS software and subsequently the Kruskal-Wallis $H$ test was applied, which followed by Mann-Whitney U test. All data were analyzed using SPSS statistical software, version 26 (SPSS Inc., Chicago, IL).
Table 2. The most constituents of extraction, Satureja rechingeri Jamzad.

\begin{tabular}{ccc}
\hline \multirow{2}{*}{ ingredients } & \multicolumn{2}{c}{$G C \%$} \\
\cline { 2 - 3 } a-thujene & Aqueous & RI \\
a-pinene & 0.12 & 926 \\
a-pinene & 0.11 & 937 \\
camphene & 0.11 & 937 \\
$\beta$-pinene & 0.05 & 950 \\
myrcene & 0.05 & 977 \\
$\alpha$-phellandrene & 0.20 & 988 \\
$\alpha$-terpinene & 0.15 & 1001 \\
$\rho$-cymene & 0.41 & 1016 \\
$\gamma$-terpinene & 3.11 & 1021 \\
thymol & 1.63 & 1061 \\
carvacrol & 2.13 & 1288 \\
Eugenol & 83.2 & 1298 \\
caryophyllene oxide & 0.21 & 1354 \\
Sum & 0.27 & 1584 \\
\hline RI = retention indices. & 91.64 &
\end{tabular}

\section{Results and discussion}

The chemical composition of $S$. rechingeri Jamzad extract was evaluated by GC-MS. The results (Table 2) exhibited that the major components of the extract $(90.07 \%)$ were carvacrol (83.20\%) p-cymene $(3.11 \%)$, thymol $(2.13 \%)$ and $\gamma$-terpinene (1.63\%) as Monoterpene combinations, which find in more than 100 herbs. The p-cymene is a well-known combination becomes the most important monoterpene finding in herbal medicines with antioxidant, antimicrobial, and anticancer properties as well as cytokine modulation (Marchese et al., 2017). The cell membrane of both Gram-negative and positive bacteria were meaningfully impaired after exposure to $\alpha$-terpin $l, \gamma$-terpinene, 
and eugenol (Oyedemi et al., 2009). Carvacrol is the major combination of $S$. rechingeri extract (Table 2) can chelate binding sites and reduce metal ions (Karmous et al., 2020) resulting a

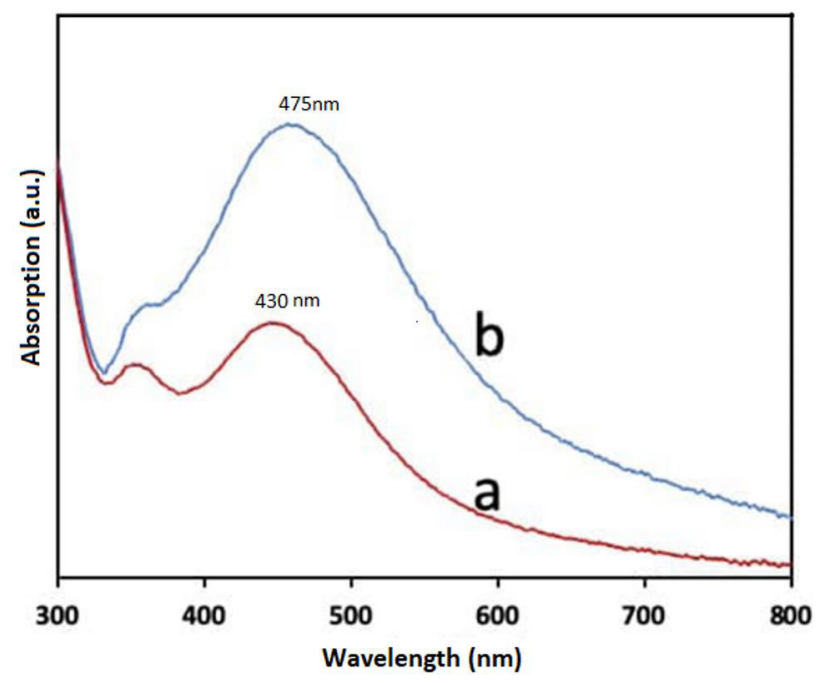

Figure 3. UV-Vis absorption spectra of Satureja rechingeri/AgNPs produced through ultrasound (a) and photochemical (b) methods. safe production of nanoparticles through green biosynthesis. Thus, the produced $S$. rechingeri/AgNPs nanocomposite can be act as safe antibacterial compare to AgNPs.

Routinely, UV-Vis peak of AgNPs, which imply on the formation Ag-NPs, is in the range of 400-500nm depending on their size, shape and distribution in the aqueous solution (Gomaa, 2017). In the UV-Visible spectrum of produced S-AgNPs through the ultrasound and photochemical methods (Figure 3), the strong wide peak was detected at 430 and $475 \mathrm{~nm}$, respectively in agreement with the findings of Ashraf et al. (2016) exhibited the widening peak of AgNPs was performed at $455 \mathrm{~nm}$. Broadening of the peaks (Figure 3) revealed that the AgNPs were polydispersed. Differences between the two peaks of wavelengths (Figure 3) confirmed also the TEM result (Figure 4), indicating smaller AgNPs produced through the ultrasound method than the photochemical one. TEM images display the size and dispersion of green synthesized AgNPs. The AgNPs diameter was different (Figure 4). These particles were well dispersed, with shapes of distorted spherical, spherical, hexagonal and irregular. More than half of the synthesized S-AgNPs/Pho had diameter size ranging from 35-55 but approximately $75 \%$ of S-AgNPs/Ult measured smaller than $30 \mathrm{~nm}$. Due to a theory, lower wavelength indicates the greater released energy of a
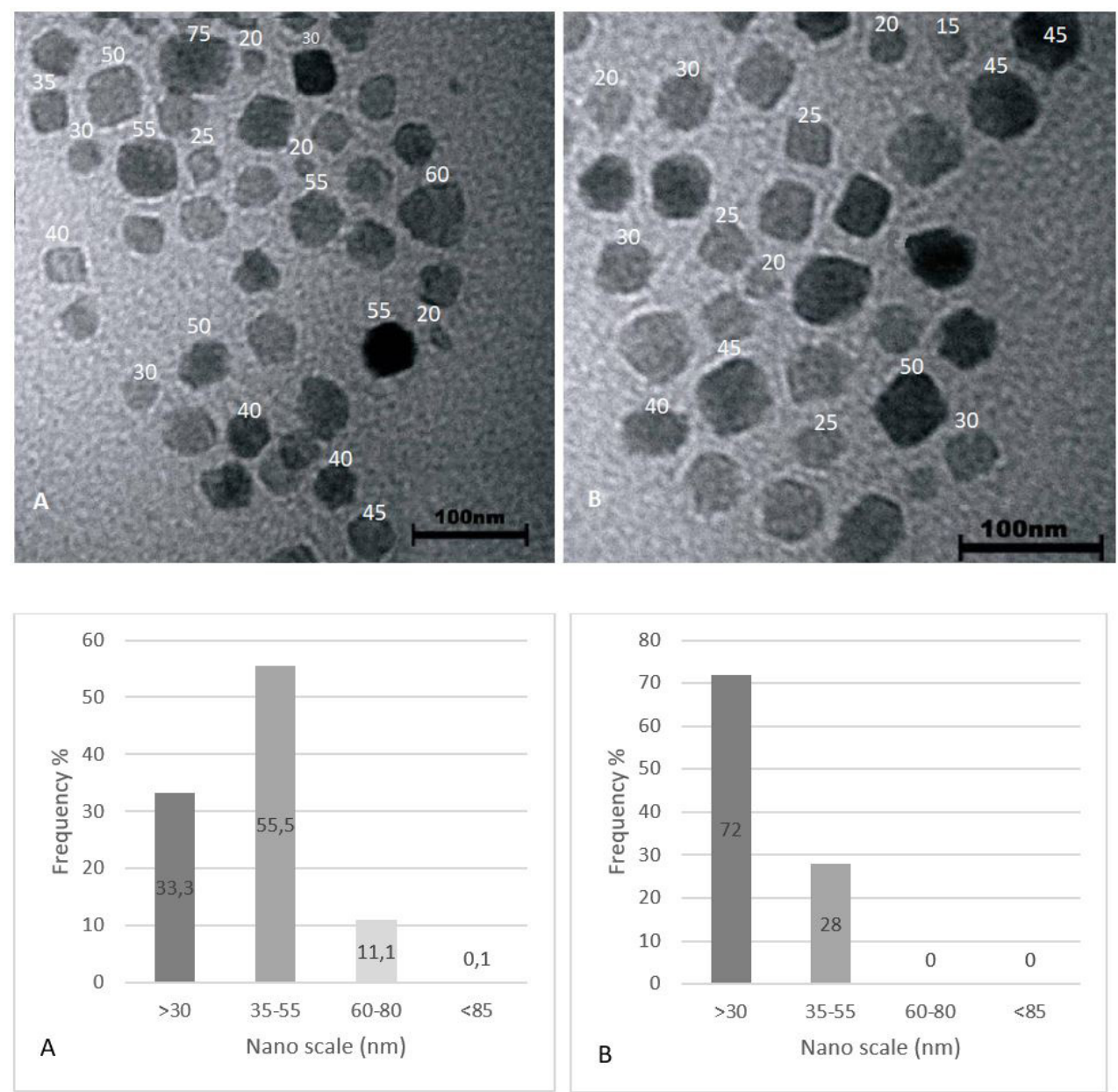

Figure 4. TEM shows the morphology of Satureja rechingeri/AgNPs produced through photochemical (A) and ultrasound method (B). S/AgNPs were chiefly distorted spherical in outline. 


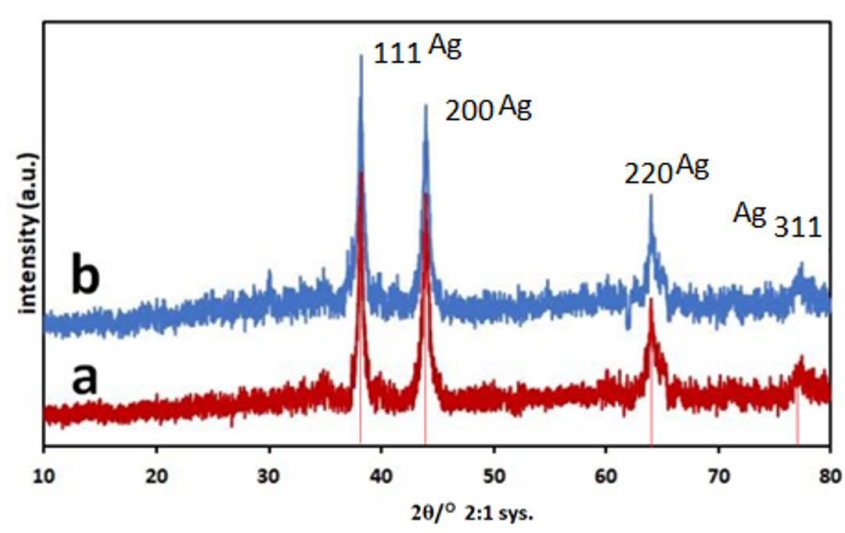

Figure 5. The XRD Pattern of green synthesized Satureja rechingeri/ AgNPs peaks may be attributed to face-centered cubic 111, 200, 220, and 311 with $2 \theta$ angles. S-AgNPs produced through the photochemical (a) and ultrasound (b) methods.

wave, indicating smaller nanoparticles in the aqueous solution (Narchin et al., 2018).

Figure 5 shows X-ray diffraction (XRD) patterns of Ag-NPs implied on the crystalline arrangement. All S/AgNP samples, which their peaks were observed at $2 \theta$ values of $38.3182,44.4975$, 64.6119 and 77.5385 could be pertinent to $111,200,220$, and 311 AgNPs-crystal structures. This pattern had a similar XRD outline compared to the standard powder diffraction card of Joint Committee on Powder Diffraction Standards (Theivasanthi \& Alagar, 2012). The peak density of biosynthesized S-AgNPs revealed the high value of the crystallinity of AgNPs while the wide peaks indicating small size in crystallinity. In addition to the observed peaks (Figure 5), a few non-routine determined peaks could indicate the presence of other phytochemicals in mixture (Firoozi et al., 2016). The XRD pattern of S-AgNPs peaks (Figure 5) was exactly in agreement with another study (Gomaa, 2017), indicating an appropriate green synthesis of silver nanoparticles. This result (Figure 5) indicated that the application of the ultrasound method resulted in smaller nanoscale of AgNPs (Figure 5b), which in turn showed a stronger antimicrobial activity compared to larger ones (Sotiriou \& Pratsinis, 2010). Such smaller nano-particles have greater contact surface area and release more Ag+ demonstrating great efficiency (Sotiriou \& Pratsinis, 2010).

Antibacterial activity of the biosynthesized AgNPs is summarized in Table 3. The result showed, count of all bacteria $(\log \mathrm{CFU} / \mathrm{g})$ obtained from all trout samples increased in a time-dependent manner. the maximum allowable limit (MAL) is $6 \log \mathrm{CFU} / \mathrm{g}$ for MBC and PBC (Mol et al., 2007). According to the author's experiences (not published), spoilage bacteria are extremely activated after 5-7 days in rainbow trout preserved at refrigerated temperature. Generally, use of S-AgNP/Ult. PVA or S-AgNP/Pho.PVA resulted in MBC decrease less than MAL up to 7 th day in fish preserved at 4 and $8{ }^{\circ} \mathrm{C}$. Due to $\mathrm{MBC}$ normally grow at moderate temperatures between 20 and $45^{\circ} \mathrm{C}$, refrigerated temperature inhibited its growth well so that the MBC close to $6 \log \mathrm{CFU} / \mathrm{g}$ is indicating the fish spoilage (Mol et al., 2007). The MBC load (Table 3) obtained from fish coated with
S-Aqueous/PVA were significantly lower than those of control approximately by $1 \mathrm{log}$ CFU/g for all sampling days, with the exception of the third day $(4.55 \pm 0.04 \log \mathrm{CFU} / \mathrm{g})$ showed a higher value $(\mathrm{p}<0.05)$ than that of control $(3.70 \pm 0.04 \log \mathrm{CFU} / \mathrm{g})$.

The lowest value of the MBC $(1.42 \pm 0.2 \mathrm{log} \mathrm{CFU} / \mathrm{g})$ was observed in G7 trout samples wrapped with S-AgNP/Pho.PVA films with no significant difference $(\mathrm{p}>0.05)$ compared to that of S-AgNP/Ult.PVA on the first day $(1.65 \pm 0.2 \log \mathrm{CFU} / \mathrm{g})$ at $4{ }^{\circ} \mathrm{C}$. Gadus morhua fillets (Mizielińska et al., 2018) were wrapped with $\mathrm{ZnO}$.NPs along with $2 \%$ polylysine postponed the growth of $\mathrm{MBC}$ reached 5 and $7 \mathrm{log} \mathrm{CFU} / \mathrm{g}$ on $3 \mathrm{rd}$ and 6 th day against this study, MBC were $2.68 \pm 0.04$ and $3.86 \pm 0.05$, respectively in fish samples coated with S-AgNP/Ult.PVA on 3rd and 7th $\mathrm{d}$ with no statistical difference $(\mathrm{p}>0.05)$ compared to those of samples were wrapped with S-AgNP/Pho.PVA (Table 3). Similarly, the $\mathrm{MBC}$ increasingly reached $5.5 \mathrm{log} \mathrm{CFU} / \mathrm{g}$ in rainbow trout fillets coated with alkaline treated protein (AlPC) after $7 \mathrm{~d}$ at cold storage and surprisingly the slope was reduced after $7 \mathrm{~d}$ so that the $\mathrm{MBC}$ reached $6 \log \mathrm{CFU} / \mathrm{g}$ on day 11 of cold storage (Özyurt et al., 2015).

On the 7th day (Table 3), MBC was remarkably decreased than MAL by about 2.1, and 2.0, $\log$ CFU/g, respectively for fish samples enclosed in S-AgNP/Ult.PVA and S-AgNP/Pho.PVA preserved at $4{ }^{\circ} \mathrm{C}$ while those of the control group $(5.83 \pm 0.05)$ showed no significant difference $(\mathrm{P}>0.05)$ compared to the MAL at the same conditions. The $\mathrm{MBC}$ reached $5.33 \log \mathrm{CFU} / \mathrm{g}$ after $9 \mathrm{~d}$ (Maghami et al., 2019) while the Huso huso fillets wrapped with chitosan-NPs activated with fennel essential oil (EO) relatively in agreement to this study showed the $\mathrm{MBC}$ was $3.86 \pm 0.05$ and $7.75 \pm 0.02 \log \mathrm{CFU} / \mathrm{g}$ in fish coated with S-AgNP/Ult.PVA with no significant difference ( $p>0.05$ ) compared to those of S-AgNP/Pho.PVA on 7 th and 14th day, respectively indicating that the MBC might be less than MAL (6 log CFU/g) and prolonged the shelf life up to 9th day, which was not analyzed in this study. Based on our previous study (Barani et al., 2018), LDPE/TiO2/Ag NPs could postpone the growth of mesophilic bacteria (6 log CFU/g) up to 14th day while its control reached this value on 6th day. The initial MBC (Barani et al., 2018) was less by $1 \log$ CFU/g than that of this study (Table 3 ), which could be a justification for the difference between $\mathrm{MBC}$ values of both studies showing the similarity efficiencies of LDPE/TiO2/Ag NPs and the AgNP/PVA (both types) on reduction of MBC in fish fillets. The value of $\mathrm{MBC}$ of all treatments (G3-G8) were significantly $(\mathrm{p}<0.05)$ higher at $8{ }^{\circ} \mathrm{C}$ compared to those preserved at $4{ }^{\circ} \mathrm{C}$.

Usually, the consumers are interested in preparing fresh fish preserved in refrigerated than frozen ones due to their nutritional values. The PBC becomes more important than MBC in the shelf-life quality evaluation (Quan et al., 2020; Seifzadeh \& Rabbani Khorasgani, 2020). On the first day, the lowest value of $\mathrm{PBC}$ was observed (Table 3 ) in trout samples wrapped with S-AgNP/Ult.PVA (2.85 $\pm 0.02 \log$ CFU/g) with no significant difference $(\mathrm{P}>0.05)$ compared to those of S-AgNP/Pho.PVA (3.04 $\pm 0.02 \log$ CFU/g). The psychrophiles grew fast at $4{ }^{\circ} \mathrm{C}$ and no growth was observed at $8^{\circ} \mathrm{C}$ after $3 \mathrm{rd}$ day of cold preservation, irrespective of the types of coating and sampling days. On the other hands, S-Aqueous/PVA showed the 
Table 3. The effect of nano- extract fabrication type at various temperatures and days on the bacterial count $(\log$ CFU/g) of selected bacteria $(n=3)$.

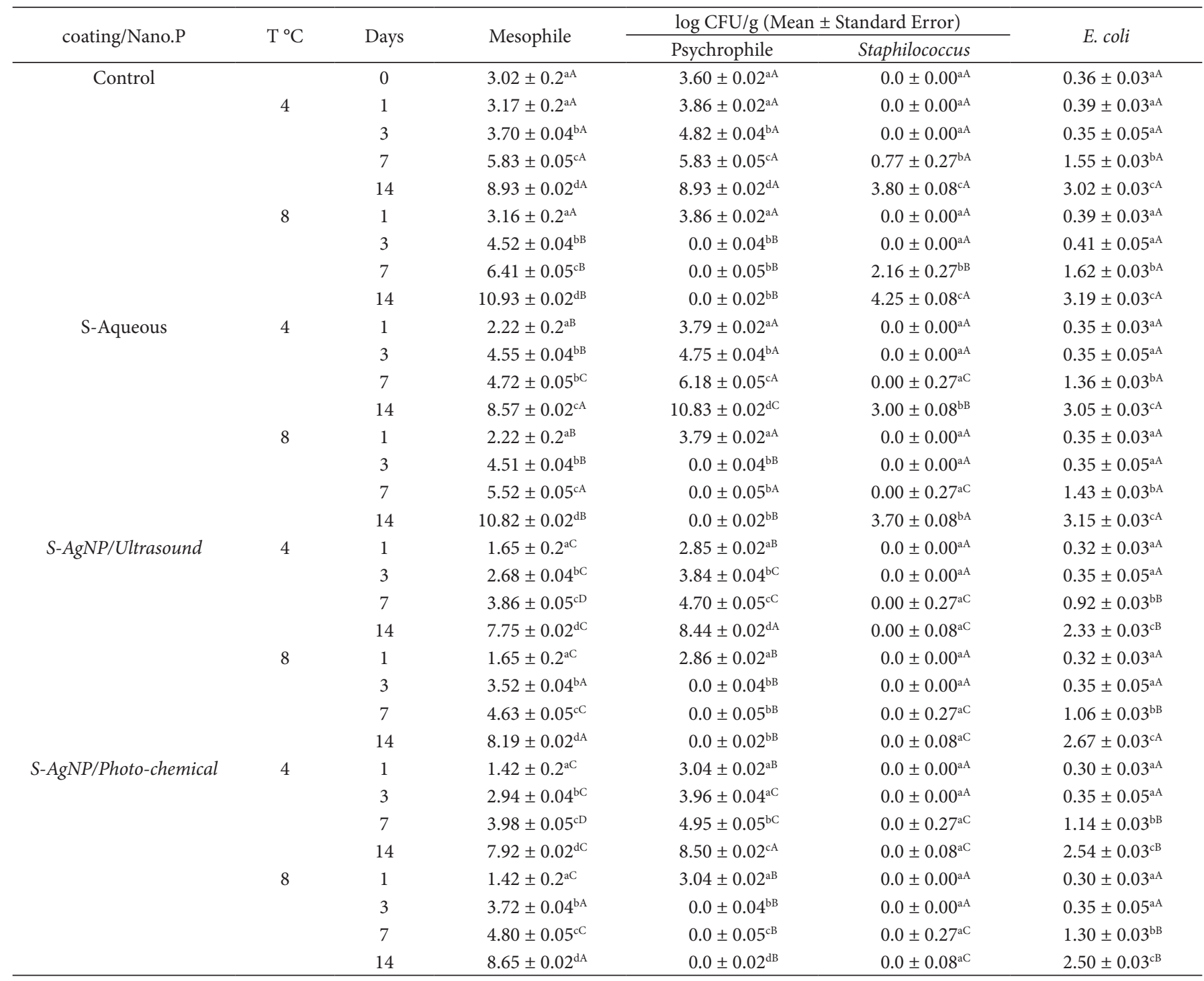

Extract/Nano.P: The production methods of S. rechingeri $-\mathrm{Ag} / \mathrm{NPs}$; T: Temperature. Different small superscripts in each extract group for each temperature indicate a significant difference $(\mathrm{p}<0.05)$. To compare all groups, capital superscripts in each column, and the same days show a significant difference $(\mathrm{p}<0.05)$.

unpredictable values in sampling days and had no any acceptable effect on reduction of $\mathrm{PBC}$. It was significantly increased up to $14 \mathrm{~d}(10.83 \pm 0.02 \mathrm{lof} \mathrm{CFU} / \mathrm{g})$. On the third day of preservation, the least $\mathrm{PBC}$ was also observed in fish samples wrapped with S-AgNP/Ult.PVA films ( $3.84 \pm 0.04 \log \mathrm{CFU} / \mathrm{g})$, and less than that of Aqueous/PVA composites by about $1 \log \mathrm{CFU} / \mathrm{g}(\mathrm{p}<0.05)$ at $4{ }^{\circ} \mathrm{C}$ and had no significant difference ( $\left.>0.05\right)$ compared to that of S-AgNP/Pho.PVA films at the same condition. After $7 \mathrm{~d}$, The PBC of G5 samples $(4.70 \pm 0.05 \log \mathrm{CFU} / \mathrm{g})$ were less than the values of both control (G1), S-Aqueous/PVA (G3) by about 1.1 and $1,5 \log \mathrm{CFU} / \mathrm{g}(\mathrm{p}<0.05)$, respectively and group of S-AgNP/Pho.PVA (by $0.25 \log \mathrm{CFU} / \mathrm{g}$ ) with an insignificant difference $(\mathrm{p}>0.05)$. The PBC of trout samples incorporated with thymol nanoemulsion (Meral et al., 2019) at a nano-scale (smaller than $70 \mathrm{~nm}$ ) was reached $5.70 \log \mathrm{CFU} / \mathrm{g}$ on 7 th day at refrigerated temperature (from $3.95 \mathrm{log} \mathrm{CFU} / \mathrm{g}$ on 1st day) greater than that of the trout samples (Table 3) enclosed in S-AgNP/Ult.
PVA (4.70 $\log \mathrm{CFU} / \mathrm{g}$ ) or S-AgNP/Ult.Pho (4.95 log CFU/g) with NPs almost scaled less than $30-35 \mathrm{~nm}$ (Figure 4) indicating the smaller the NPs the greeter the antibacterial efficiency (Sotiriou \& Pratsinis, 2010). Applying $\mathrm{ZnO}$ nanocomposite along with Mentha spicata could retard psychrophilic bacteria growth up to 7th day at the MAL level (Shahbazi \& Shavisi, 2018a) higher than the findings of this study (Table 3 ) exhibited PBC reached 3.84 and $3.96 \log \mathrm{CFU} / \mathrm{g}$, respectively in rainbow trout fillets covered with S-AgNP/Ult.PVA and S-AgNP/Pho.PVA at $4^{\circ} \mathrm{C}$. The psychrophilic microorganisms are responsible for off-odor occurred in the most spoilage of foods (Meral et al., 2019). Farsi gum-based coatings incorporated with clove and Shirazi thyme essential oil emulsions were used to prolong the shelf-life of rainbow trout fillets at refrigerated temperature. Despite the great bactericidal properties of the mentioned essential oils (Majdinasab et al., 2020), the resultant emulsion could not significantly decrease the amount of psychrophilic bacteria 
even increase it so that the PBC incredibly went up from 1st (4-5 log CFU/g) to 4 th $\mathrm{d}$ (more than $6 \log \mathrm{CFU} / \mathrm{g}$ ) more than the MAL (Shahbazi \& Shavisi, 2018a), which could be due to the method of extraction or sonication (Dehghani et al., 2018). The sensory criteria showed the silver pomfret stored in ice could be edible up to 12 th day, while the PBC was $6.0 \mathrm{log}$ CFU/g on $3 \mathrm{rd}$ day and remarkably increased afterward (Fazlara et al., 2014).

The antimicrobial activities of AgNPs on Gram-negative bacteria was shown to be greater than Gram-positive bacteria which could be due to the less thickness wall of Gram-negative ones (Seong \& Lee, 2017). Monoterpenes, the major ingredients (more than 90\%) in S. rechingeri, inhibit the growth of S. aureus more than E. coli (Trombetta et al., 2005) in agreement with other studies (Alboofetileh et al., 2014; Alizadeh, 2015; Paredes et al., 2014; Pirtarighat et al., 2019) confirmed that S. aureus was more sensitive than E. coli. Similar to the findings of this study (Table 3), a new finding indicated that $S$. aureus was more sensitive to chitosan/PVA nanocomposite than E. coli (Hajji et al., 2016). Dislike, The S-AgNP/Pho extract showed greater effect on the both bacteria (same effectiveness) compared to S-AgNP/Ult one (Narchin et al., 2018). The afore-mentioned differences of the efficiency on the both bacteria may be due to a few factors such as size of AgNPs, types of nano-metals (Meral et al., 2019), bacterial resistance, growth phase of herbs, major composition of extract, and the experiment methodology (Alizadeh, 2015; Paredes et al., 2014). However, In the rainbow trout fillets were packed in chitosan- $\mathrm{ZnO}$ films containing different concentrations of pomegranate peel extract (1.5\%), the value for $S$. aureus was $2.0 \log$ CFU/g at $6 \mathrm{~d}$, which were eliminated from the fillets on $7 \mathrm{~d}$ at $4{ }^{\circ} \mathrm{C}$ (Shahbazi \& Shavisi, 2018b) a one week delay in comparison to this study (Table 3), which could be due to the different use of extracts, because the volume of NPs required for $S$. aureusgrowth inhibition impacted by $\mathrm{ZnO}$ and $\mathrm{Ag}$ nanocomposites was usually the same (Salem et al., 2015). The growth of S. aureus neither observed in the trout fillets coated with S-AgNP/PVAUlt nor in those of S-AgNP/PVA-Pho films during the study (14d). Against the control group on which the occurrence of $S$. aureus was began on 7 th day $\left(0.77 \pm 0.27 \log \mathrm{CFU} / g\right.$ at $\left.4^{\circ} \mathrm{C}\right), S$. aureus was observed from the 14th day in the fillets of $\mathrm{S}$-Aqueous groups, so that the values were $3.00 \pm 0.08$ and $3.70 \pm 0.08 \log$ $\mathrm{CFU} / \mathrm{g}$, respectively at 4 and $8{ }^{\circ} \mathrm{C}(\mathrm{p}<0.05)$. On 12 th day, $S$. aureus count was reached $3.38 \pm 0.05 \mathrm{log} \mathrm{CFU} / \mathrm{g}$ in the fish covered with PVA-gelatin films incorporated with Amaranthus leaf extract (Kanatt, 2020) greater than those of the fish samples of this study even in S-Aqueous/PVA group (Table 3).

Regardless of whether the S-NPs were incorporated with PVA or what temperature degree was applied, E. coli count was increased with a time-dependent manner up to 7 th day so that the least value was measured in G7 on the first day $(0.30 \pm 0.03 \log \mathrm{CFU} / g)$ with insignificant difference $(\mathrm{p}>0.05)$ compared to those of other groups. Dislike, poly sulfobetaine methacrylate along with bacterial nanocellulose could decrease $E$. coli count by $1.1 \log$ CFU/mL after $24 \mathrm{~h}$ (reached $8.5 \log \mathrm{CFU} / \mathrm{mL}$ ) but showed no effective reduction (Vilela et al., 2019). Dislike, alginate/carboxyl methylcellulose nanocomposite film along with clove- EO (1.5\%), a combination without $\mathrm{Ag}^{+}$ions, could significantly decrease E. coli counts in the silver carp fillet from $3 \log \mathrm{CFU} / \mathrm{g}$ at first day to approximate $1 \mathrm{log} \mathrm{CFU} / \mathrm{g}$ on $12 \mathrm{~d}$
(Jalali et al., 2016). On 7 and 14d, trout samples of G5 coated with S-AgNP/Ult-PVA films had the lowest E. coli load, while it reached $0.92 \pm 0.03$ and $2.33 \pm 0.03 \log \mathrm{CFU} / \mathrm{g}$, respectively less than those of control and S-Aqueous/PVA samples $(\mathrm{p}<0.05)$, but an insignificant difference $(\mathrm{p}>0.05)$ was observed in comparison to those of G7 $(1.14 \pm 0.03$ and $2.54 \pm 0.03 \log \mathrm{CFU} / \mathrm{g}$, respectively) in which the samples enclosed in S-AgNP/PVAPho films. Thus, The less effectiveness of the both nano-groups (S-AgNP/Ult-PVA, AgNP/PVA-Pho) on eliminating the $E$. coli (Table 3) was observed, which may be due to the resistance formation to AgNPs due to the production of flagellin, an adhesive protein of bacterial flagellum, resulted in aggregation of AgNPs (Kaweeteerawat et al., 2017) or due to the cell wall lipopolysaccharides (Alboofetileh et al., 2014), which in turn retarded their antibacterial efficiency. This result indicated that both S-AgNP/PVA films couldn't completely eradicate $E$. coli in fresh fish preserved in refrigerator.

\subsection{Salmonella spp were not detected from the samples of whole groups (data was not included)}

The Sensory properties of rainbow trout fillets coated with different nanocomposite films during refrigerated storage are presented in Table 4 . The fish samples were considered acceptable, while their sensorial scores were less than 4 (moderate). The score for appearance, color, odor, texture, and general acceptability increased $(\mathrm{P}<0.05)$ over the cold storage during 14 days. The above-mentioned criteria of control samples and trout wrapped with Aqueous/PVA were considered 'unacceptable' from the 3rd day due to less efficiency of coatings, consequently fish deterioration and high activity of microbial spoilage throughout the storage, regardless of the temperature degree. Dislike to this study (Table 4) showed that the fish scores of all criteria were less than 4 (moderate) up to 7 th day in the trout enfolded by S-AgNP/PVA-Ult and S-AgNP/PVA-pho ( $\mathrm{p}>0.05)$, surprisingly the shelf life of trout fillets encased in Chitosan Coatings incorporated with Mentha spicata EO and zinc oxide nanoparticles extended up to $16 \mathrm{~d}$ at refrigerated condition (Shahbazi \& Shavisi, 2018a) in which the PBC significantly was less than MAL by $3 \log \mathrm{CFU} / \mathrm{g}$. However, the samples coated with S-AgNP/PVA-pho and S-AgNP/PVA-Ult composites had a longer shelf-life up to 7 days (Table 4), as compared to the control and S/Aqueous fish samples. Likewise, the fillets of mackerel (Scomberomorus commerson) wrapped with pomegranate peel extract along with gelatin (G)-polycaprolactone composite film caused the shelf life to be increased up to 6 days (Khodanazary, 2019). In contrast, the shelf life of sea bass slices was prolonged up to 12 days, while they wrapped with $\mathrm{ZnO}$ nanoparticles/ basil leaf-EO loaded in LDPE compared to control (Arfat et al., 2015). Unexpectedly, off-flavor was not documented by the panelists up to 16 days of refrigerated-trout fillets enfolded by nanochitosan alone or incorporated with $\mathrm{Na}$ acetate while PBC was more than $6 \log$ CFU/g on 6th day (Kamani et al., 2020). Curcumin- nanoemulsion (Khoshbouy Lahidjani et al., 2020), as a strong well-known antimicrobial combination, could not postpone the spoilage of trout fillet more than 5 days when they were preserved at refrigerated temperature. 
Table 4. The effect of nano- extract types and temperature on sensory criteria for preserved trout fillets $(n=3)$.

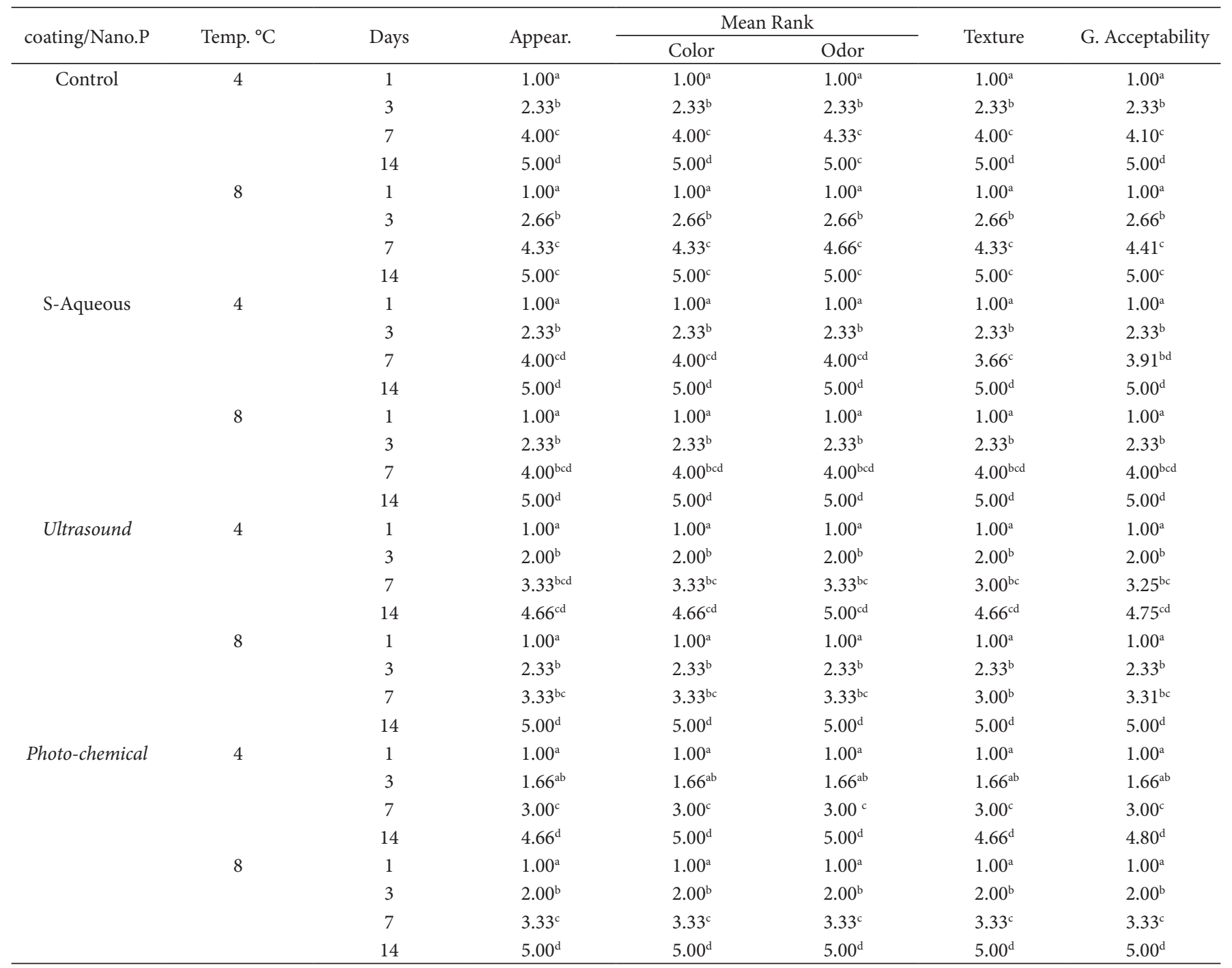

Extract/Nano.P: The production methods of S. rechingeri $-\mathrm{Ag} / \mathrm{NPs}$; Apear. $=$ Appearance; Temp $=$ Temperature, G. $=$ General. Dissimilar superscripts show significant difference $(\mathrm{p}<0.05)$ in each column among 32 groups.

\section{Conclusion}

To conclude, the present study seeks to address using the green synthesis of AgNPs/S. rechingeri. The physical targeted criteria of AgNPs fabricated through ultrasound, and photochemical methods resulted in preferred properties, features, and desired nano-scale. The importance of these techniques is related to their antimicrobial efficiency and the environmentally friendly AgNPs-S. rechingeri/PVA synthesis. AgNP/Ult.PVA and S-AgNP/Pho.PVA films with size mostly smaller than $35-50 \mathrm{~nm}$ average diameter were effectively postponed the mesophilic and psychrophilic bacteria growth until the 7th day of cold storage period, while fish samples enclosed in S. rechingeri/PVA and control films could be edible up to 3rd day of cold storage due to their counts exceeded $6 \log \mathrm{CFU} / \mathrm{g}$. The bacteriological analyses were confirmed with the sensory evaluation so that $O$. mykiss samples enfolded with AgNP/Ult.PVA and S-AgNP/Pho.PVA films had desirable sensory criteria which made them be edible up to the 7 th day even more. These two types of films were also capable to completely eliminate S. aureus from O. mykiss samples up to two weeks. The E. coli were less sensitive to AgNP/Ult.PVA and S-AgNP/Pho.PVA films compared to the other afore-mentioned bacteria through the cold storage. It suggested that AgNP/Ult. PVA and S-AgNP/Pho.PVA films can be used as a coating films for O. mykiss at cold preservation to prolong the shelf life up to 7th day in fish trails.

\section{Acknowledgements}

Technical support for the thesis accomplishment by the Islamic Azad University is gratefully acknowledged.

\section{References}

Alaraidh, I. A., Ibrahim, M. M., \& El-Gaaly, G. A. (2014). Evaluation of green synthesis of Ag nanoparticles using Eruca sativa and Spinacia oleracea leaf extracts and their antimicrobial activity. Iranian Journal of Biotechnology, 12(1), 50-55. http://dx.doi.org/10.5812/ijb.12392. 
Alboofetileh, M., Rezaei, M., Hosseini, H., \& Abdollahi, M. (2014). Antimicrobial activity of alginate/clay nanocomposite films enriched with essential oils against three common foodborne pathogens. Food Control, 36(1), 1-7. http://dx.doi.org/10.1016/j.foodcont.2013.07.037.

Alizadeh, A. (2015). Essential oil composition, phenolic content, antioxidant, and antimicrobial activity of cultivated Satureja rechingeri Jamzad at different phenological stages. Zeitschrift für Naturforschung C, 70(3-4), 51-58. http://dx.doi.org/10.1515/znc2014-4121. PMid:25924231.

Alsaraf, S., Hadi, Z., Al-Lawati, W. M., Al Lawati, A. A., \& Khan, S. A. (2020). Chemical composition, in vitro antibacterial and antioxidant potential of Omani Thyme essential oil along with in silico studies of its major constituent. Journal of King Saud University-Science, 32(1), 1021-1028. http://dx.doi.org/10.1016/j.jksus.2019.09.006.

Anvar, A., Haghighat Kajavi, S., Ahari, H., Sharifan, A., Motallebi, A., Kakoolaki, S., \& Paidari, S. (2019). Evaluation of the antibacterial effects of Ag-Tio2 nanoparticles and optimization of its migration to sturgeon caviar (Beluga). Iranian Journal of Fisheries Science, 18, 954-967. http://dx.doi.org/10.22092/ijfs.2019.118074.

Arfat, Y. A., Benjakul, S., Vongkamjan, K., Sumpavapol, P., \& Yarnpakdee, S. (2015). Shelf-life extension of refrigerated sea bass slices wrapped with fish protein isolate/fish skin gelatin- $\mathrm{ZnO}$ nanocomposite film incorporated with basil leaf essential oil. Journal of Food Science and Technology, 52(10), 6182-6193. http://dx.doi.org/10.1007/s13197014-1706-y. PMid:26396365.

Ashraf, J. M., Ansari, M. A., Khan, H. M., Alzohairy, M. A., \& Choi, I. (2016). Green synthesis of silver nanoparticles and characterization of their inhibitory effects on AGEs formation using biophysical techniques. Scientific Reports, 6(1), 20414. http://dx.doi.org/10.1038/ srep20414. PMid:26829907.

Barani, S., Ahari, H., \& Bazgir, S. (2018). Increasing the shelf life of pikeperch (Sander lucioperca) fillets affected by low-density polyethylene/Ag/TiO2 nanocomposites experimentally produced by sol-gel and melt-mixing methods. International Journal of Food Properties, 21(1), 1923-1936. http://dx.doi.org/10.1080/10942912. 2018.1508162.

Ceylan, Z., Meral, R., Karakaş, C. Y., Dertli, E., \& Yilmaz, M. T. (2018). A novel strategy for probiotic bacteria: Ensuring microbial stability of fish fillets using characterized probiotic bacteria-loaded nanofibers. Innovative Food Science \& Emerging Technologies, 48, 212-218. http:// dx.doi.org/10.1016/j.ifset.2018.07.002.

Dehghani, P., Hosseini, S. M. H., Golmakani, M.-T., Majdinasab, M., \& Esteghlal, S. (2018). Shelf-life extension of refrigerated rainbow trout fillets using total Farsi gum-based coatings containing clove and thyme essential oils emulsions. Food Hydrocolloids, 77, 677-688. http://dx.doi.org/10.1016/j.foodhyd.2017.11.009.

Dehghanizade, S., Arasteh, J., \& Mirzaie, A. (2018). Green synthesis of silver nanoparticles using Anthemis atropatana extract: characterization and in vitro biological activities. Artificial Cells, Nanomedicine, and Biotechnology, 46(1), 160-168. http://dx.doi.org/10.1080/21691401 .2017.1304402. PMid:28368661.

Demir, D., Ceylan, S., Gül, G., İyigündoğdu, Z., \& Bölgen, N. (2019). Green synthesized silver nanoparticles loaded PVA/Starch cryogel scaffolds with antibacterial properties. Tehnički Glasnik, 13(1), 1-6. http://dx.doi.org/10.31803/tg-20180131161141.

Devi, J. M., \& Umadevi, M. (2014). Synthesis and characterization of Silver-PVA nanocomposite for sensor and antibacterial applications. Journal of Cluster Science, 25(2), 639-650. http://dx.doi.org/10.1007/ s10876-013-0660-6.

Diler, A., \& Genç, İ. Y. (2018). A practical quality index method (QIM) developed for aquacultured rainbow trout (Oncorhynchus mykiss).
International Journal of Food Properties, 21(1), 858-867. http:// dx.doi.org/10.1080/10942912.2018.1466326.

Emamifar, A., Kadivar, M., Shahedi, M., \& Soleimanian-Zad, S. (2010). Evaluation of nanocomposite packaging containing Ag and $\mathrm{ZnO}$ on shelf life of fresh orange juice. Innovative Food Science \& Emerging Technologies, 11(4), 742-748. http://dx.doi.org/10.1016/j. ifset.2010.06.003.

Fazlara, A., Yavari, V., Abhari Segonbad, H., \& Rajabzadeh Ghatromi, E. (2014). Predictive models for evaluation of mesophilic and psychrophilic bacterial loads in muscles of fresh ice-stored silver pomfret by impediometric technique. Iranian Journal of Fisheries Science, 13, 303-318.

Firoozi, S., Jamzad, M., \& Yari, M. (2016). Biologically synthesized silver nanoparticles by aqueous extract of Satureja intermedia CA Mey and the evaluation of total phenolic and flavonoid contents and antioxidant activity. Journal of Nanostructure in Chemistry, 6(4), 357-364. http://dx.doi.org/10.1007/s40097-016-0207-0.

Gomaa, E. Z. (2017). Antimicrobial, antioxidant and antitumor activities of silver nanoparticles synthesized by Allium cepa extract: a green approach. Journal of Genetic Engineering and Biotechnology, 15(1), 49-57. http://dx.doi.org/10.1016/j.jgeb.2016.12.002. PMid:30647641.

Hajji, S., Chaker, A., Jridi, M., Maalej, H., Jellouli, K., Boufi, S., \& Nasri, M. (2016). Structural analysis, and antioxidant and antibacterial properties of chitosan-poly (vinyl alcohol) biodegradable films. Environmental Science and Pollution Research International, 23(15), 15310-15320. http://dx.doi.org/10.1007/s11356-016-6699-9. PMid:27106077.

Jaiswal, L., Shankar, S., Rhim, J.-W., \& Hahm, D.-H. (2020). Ligninmediated green synthesis of AgNPs in carrageenan matrix for wound dressing applications. International Journal of Biological Macromolecules, 159, 859-869. http://dx.doi.org/10.1016/j.ijbiomac.2020.05.145. PMid:32445819.

Jalali, N., Ariiai, P., \& Fattahi, E. (2016). Effect of alginate/carboxyl methyl cellulose composite coating incorporated with clove essential oil on the quality of silver carp fillet and Escherichia coli O157: H7 inhibition during refrigerated storage. Journal of Food Science and Technology, 53(1), 757-765. http://dx.doi.org/10.1007/s13197-0152060-4. PMid:26787996.

Kamani, J., Motalbei Moghanjoghi, A., Razavilar, V., \& Rokni, N. (2020). Effects of nanochitosan with and without sodium acetate coating on Pseudomonas fluorescens and the quality of refrigerated rainbow trout filets. Iranian Journal of Fisheries Science, 19, 1479-1499. http:// dx.doi.org/10.22092/ijfs.2020.120788.

Kanatt, S. R. (2020). Development of active/intelligent food packaging film containing Amaranthus leaf extract for shelf life extension of chicken/fish during chilled storage. Food Packaging and Shelf Life, 24, 100506. http://dx.doi.org/10.1016/j.fpsl.2020.100506.

Karmous, I., Pandey, A., Haj, K. B., \& Chaoui, A. (2020). Efficiency of the green synthesized nanoparticles as new tools in cancer therapy: insights on plant-based bioengineered nanoparticles, biophysical properties, and anticancer roles. Biological Trace Element Research, 196(1), 330-342. http://dx.doi.org/10.1007/s12011-019-01895-0. PMid:31512171.

Kaweeteerawat, C., Na Ubol, P., Sangmuang, S., Aueviriyavit, S., \& Maniratanachote, R. (2017). Mechanisms of antibiotic resistance in bacteria mediated by silver nanoparticles. Journal of Toxicology and Environmental Health. Part A., 80(23-24), 1276-1289. http://dx.doi. org/10.1080/15287394.2017.1376727. PMid:29020531.

Khodanazary, A. (2019). Quality characteristics of refrigerated mackerel Scomberomorus commerson using gelatin-polycaprolactone composite film incorporated with lysozyme and pomegranate peel extract. 
International Journal of Food Properties, 22(1), 2057-2071. http:// dx.doi.org/10.1080/10942912.2019.1702997.

Khoshbouy Lahidjani, L., Ahari, H., \& Sharifan, A. (2020). Influence of curcumin-loaded nanoemulsion fabricated through emulsion phase inversion on the shelf life of Oncorhynchus mykiss stored at $4{ }^{\circ} \mathrm{C}$. Journal of Food Processing and Preservation, 44(8), e14592. http://dx.doi.org/10.1111/jfpp.14592.

Logeswari, P., Silambarasan, S., \& Abraham, J. (2015). Synthesis of silver nanoparticles using plants extract and analysis of their antimicrobial property. Journal of Saudi Chemical Society, 19(3), 311-317. http:// dx.doi.org/10.1016/j.jscs.2012.04.007.

Lotfi, S., Ahari, H., \& Sahraeyan, R. (2019). The effect of silver nanocomposite packaging based on melt mixing and sol-gel methods on shelf life extension of fresh chicken stored at $4^{\circ} \mathrm{C}$. Journal of Food Safety, 39(3), e12625. http://dx.doi.org/10.1111/jfs.12625.

Maghami, M., Motalebi, A. A., \& Anvar, S. A. A. (2019). Influence of chitosan nanoparticles and fennel essential oils (Foeniculum vulgare) on the shelf life of Huso huso fish fillets during the storage. Food Science \& Nutrition, 7(9), 3030-3041. http://dx.doi.org/10.1002/ fsn3.1161. PMid:31572596.

Majdinasab, M., Niakousari, M., Shaghaghian, S., \& Dehghani, H. (2020). Antimicrobial and antioxidant coating based on basil seed gum incorporated with Shirazi thyme and summer savory essential oils emulsions for shelf-life extension of refrigerated chicken fillets. Food Hydrocolloids, 108, 106011. http://dx.doi.org/10.1016/j. foodhyd.2020.106011.

Marchese, A., Arciola, C. R., Barbieri, R., Silva, A. S., Nabavi, S. F., Sokeng, T., Jorel, A., Izadi, M., Jafari, N. J., Suntar, I., Daglia, M., \& Nabavi, S. (2017). Update on monoterpenes as antimicrobial agents: a particular focus on p-cymene. Materials, 10(8), 947-961. http:// dx.doi.org/10.3390/ma10080947. PMid:28809799.

Mathew, S., Snigdha, S., Mathew, J., \& Radhakrishnan, E. K. (2018). Poly (vinyl alcohol): montmorillonite: boiled rice water (starch) blend film reinforced with silver nanoparticles; characterization and antibacterial properties. Applied Clay Science, 161, 464-473. http://dx.doi.org/10.1016/j.clay.2018.05.009.

Meral, R., Ceylan, Z., \& Kose, S. (2019). Limitation of microbial spoilage of rainbow trout fillets using characterized thyme oil antibacterial nanoemulsions. Journal of Food Safety, 39(4), e12644. http://dx.doi. org/10.1111/jfs.12644.

Mizielińska, M., Kowalska, U., Jarosz, M., \& Sumińska, P. (2018). A comparison of the effects of packaging containing nano $\mathrm{ZnO}$ or polylysine on the microbial purity and texture of Cod (Gadus morhua) fillets. Nanomaterials, 8(3), 158. http://dx.doi.org/10.3390/ nano8030158. PMid:29534544.

Mol, S., Erkan, N., Üçok, D., \& Tosun, Ş. Y. (2007). Effect of psychrophilic bacteria to estimate fish quality. Journal of Muscle Foods, 18(1), 120128. http://dx.doi.org/10.1111/j.1745-4573.2007.00071.x.

Narchin, F., Larijani, K., Rustaiyan, A., Ebrahimi, S. N., \& Tafvizi, F. (2018). Phytochemical synthesis of silver nanoparticles by two techniques Using Saturaja rechengri Jamzad extract: identifying and comparing in Vitro anti-proliferative activities. Advanced Pharmaceutical Bulletin, 8(2), 235. http://dx.doi.org/10.15171/ apb.2018.028. PMid:30023325.

Nascimento, C. S., Rodrigues, A. M. C., \& Silva, L. H. M. (2020). Development of a dehydrated product with edible film characteristics from mammee apple (Mammea americana L.) using Refractance Window drying. Food Science and Technology, 40(1), 245-249. http:// dx.doi.org/10.1590/fst.36218.

Navarro-Rocha, J., Andrés, M. F., Díaz, C. E., Burillo, J., \& GonzálezColoma, A. (2020). Composition and biocidal properties of essential oil from pre-domesticated Spanish Satureja Montana. Industrial Crops and Products, 145, 111958. http://dx.doi.org/10.1016/j. indcrop.2019.111958.

Nawaz, A., Xiong, Z., Li, Q., Xiong, H., Irshad, S., Chen, L., Wang, P., Zhang, M., Hina, S., \& Regenstein, J. M. (2019). Evaluation of physico-chemical, textural and sensory quality characteristics of red fish meat based fried snacks. Journal of the Science of Food and Agriculture, 99(13), 5771-5777. http://dx.doi.org/10.1002/jsfa.9845. PMid:31162676.

Nwabor, O. F., Singh, S., Paosen, S., Vongkamjan, K., \& Voravuthikunchai, S. P. (2020). Enhancing food shelf life with polyvinyl alcohol-chitosan polymer nanocomposite films from bioactive Eucalyptus leaf extracts. Food Bioscience, 36, 100609. http://dx.doi.org/10.1016/j. fbio.2020.100609.

Oyedemi, S. O., Okoh, A. I., Mabinya, L. V., Pirochenva, G., \& Afolayan, A. J. (2009). The proposed mechanism of bactericidal action of eugenol, $\propto$-terpineol and g-terpinene against Listeria monocytogenes, Streptococcus pyogenes, Proteus vulgaris and Escherichia coli. African Journal of Biotechnology, 8, 1280-1286.

Özyurt, G., Özkütük, A. S., Şimşek, A., Yeşilsu, A. F., \& Ergüven, M. (2015). Quality and shelf life of cold and frozen rainbow trout (Oncorhynchus mykiss) fillets: effects of fish protein-based biodegradable coatings. International Journal of Food Properties, 18(9), 1876-1887. http:// dx.doi.org/10.1080/10942912.2014.971182.

Paladini, E. P., Avilés, B. G., Schumacher, L., Lorenz, M., \& Urquiza, Y. R. (2019). Quality management model for perishable food in a fishing industry. Journal of Food Process Engineering, 42(6), 1-17. http://dx.doi.org/10.1111/jfpe.13171.

Paredes, D., Ortiz, C., \& Torres, R. (2014). Synthesis, characterization, and evaluation of antibacterial effect of Ag nanoparticles against Escherichia coli O157: H7 and methicillin-resistant Staphylococcus aureus (MRSA). International Journal of Nanomedicine, 9, 1717-1729. http://dx.doi.org/10.2147/IJN.S57156. PMid:24729707.

Peng, Y., Wang, Q., Shi, J., Chen, Y., \& Zhang, X. (2020). Optimization and release evaluation for tea polyphenols and chitosan composite films with regulation of glycerol and Tween. Food Science and Technology, 40(1), 162-170. http://dx.doi.org/10.1590/fst.34718.

Pirtarighat, S., Ghannadnia, M., \& Baghshahi, S. (2019). Green synthesis of silver nanoparticles using the plant extract of Salvia spinosa grown in vitro and their antibacterial activity assessment. Journal of Nanostructure in Chemistry, 9(1), 1-9. http://dx.doi.org/10.1007/ s40097-018-0291-4.

Quan, T. H., Benjakul, S., \& Hozzein, W. N. (2020). Quality and storage stability of fish tofu as affected by duck albumen hydrolysateepigalocatechin gallate conjugate. Lebensmittel-Wissenschaft + Technologie, 120, 108927. http://dx.doi.org/10.1016/j.lwt.2019.108927.

Ramires, T., Iglesias, M. A., Vitola, H. S., Núncio, A. S. P., Kroning, I. S., Kleinubing, N. R., Fiorentini, Â. M., \& Silva, W. P. (2020). First report of Escherichia coli O157: H7 in ready-to-eat sushi. Journal of Applied Microbiology, 128(1), 301-309. http://dx.doi.org/10.1111/ jam.14456. PMid:31541508.

Reddy, P. L., Deshmukh, K., Chidambaram, K., Ali, M. M. N., Sadasivuni, K. K., Kumar, Y. R., Lakshmipathy, R., \& Pasha, S. K. (2019). Dielectric properties of polyvinyl alcohol (PVA) nanocomposites filled with green synthesized zinc sulphide ( $\mathrm{ZnS}$ ) nanoparticles. Journal of Materials Science Materials in Electronics, 30(5), 4676-4687. http:// dx.doi.org/10.1007/s10854-019-00761-y.

Salem, W., Leitner, D. R., Zingl, F. G., Schratter, G., Prassl, R., Goessler, W., Reidl, J., \& Schild, S. (2015). Antibacterial activity of silver and zinc nanoparticles against Vibrio cholerae and enterotoxic Escherichia 
coli. International Journal of Medical Microbiology, 305(1), 85-95. http://dx.doi.org/10.1016/j.ijmm.2014.11.005. PMid:25466205.

Santos, C. A., Ingle, A. P., \& Rai, M. (2020). The emerging role of metallic nanoparticles in food. Applied Microbiology and Biotechnology, 104(6), 2373-2383. http://dx.doi.org/10.1007/s00253-020-10372-x. PMid:31989225.

Santoso, B., Hazirah, R., Priyanto, G. J., Hermanto, \& Sugito, (2019). Utilization of Uncaria gambir Roxb filtrate in the formation of bioactive edible films based on corn starch. Food Science and Technology, 39(4), 837-842. http://dx.doi.org/10.1590/fst.06318.

Sarab, M. L., Nouri, M., \& Tarighat-Esfanjani, A. (2019). Characteristics of Iranian traditional butter produced in Sarab in comparison with European and national standards. Progress in Nutrition, 21(1), 416421. http://dx.doi.org/10.23751/pn.v21i1-S.5932.

Seifzadeh, M., \& Rabbani Khorasgani, M. (2020). Effects of Mozafati, Piaroum, Zahedi date extracts and their combination on the chemical, microbial and sensory properties of farmed rainbow trout (Oncorhynchus mykiss) fillets during refrigeration $\left(4{ }^{\circ} \mathrm{C}\right)$. Iranian Journal of Fisheries Science, 19, 1083-1097. http://dx.doi. org/10.22092/IJFS.2020.120906.

Seong, M., \& Lee, D. G. (2017). Silver nanoparticles against Salmonella enterica serotype typhimurium: role of inner membrane dysfunction. Current Microbiology, 74(6), 661-670. http://dx.doi.org/10.1007/ s00284-017-1235-9. PMid:28321528.

Shahbazi, Y., \& Shavisi, N. (2018a). Chitosan coatings containing Mentha spicata essential oil and zinc oxide nanoparticle for shelf life extension of rainbow trout fillets. Journal of Aquatic Food Product Technology, 27(9), 986-997. http://dx.doi.org/10.1080/10498850.2018.1518945.

Shahbazi, Y., \& Shavisi, N. (2018b). Preparation of new nanocomposite film for controlling Listeria monocytogenes and Staphylococcus aureus in raw rainbow trout fillet. Nanomedicine Research Journal, 3, 79-88. http://dx.doi.org/10.22034/NMRJ.2018.02.004.

Singh, P., \& Danai, P. (2019). Green synthesis and characterization of silver nanoparticles by using Albizia Lebbeck (L.) Benth. Trends in Drug Delivery, 6, 11-16. http://dx.doi.org/10.37591/tdd.v6i2.611.
Song, X., Cheng, L., \& Tan, L. (2019). Edible iron yam and maize starch convenient food flavoring packaging films with lemon essential oil as plasticization. Food Science and Technology, 39(4), 971-979. http:// dx.doi.org/10.1590/fst.13118.

Sotiriou, G. A., \& Pratsinis, S. E. (2010). Antibacterial activity of nanosilver ions and particles. Environmental Science \& Technology, 44(14), 5649-5654. http://dx.doi.org/10.1021/ es101072s. PMid:20583805.

Souri, E., Amin, G., Farsam, H., \& Andaji, S. (2004). The antioxidant activity of some commonly used vegetables in Iranian diet. Fitoterapia, 75(6), 585-588. http://dx.doi.org/10.1016/j.fitote.2004.04.007. PMid:15351114.

Theivasanthi, T., \& Alagar, M. (2012). Electrolytic synthesis and characterizations of silver nanopowder. Nano Biomedicine and Engineering, 4(2), 58-65. http://dx.doi.org/10.5101/nbe. v4i2.p58-65.

Trombetta, D., Castelli, F., Sarpietro, M. G., Venuti, V., Cristani, M., Daniele, C., Saija, A., Mazzanti, G., \& Bisignano, G. (2005). Mechanisms of antibacterial action of three monoterpenes. Antimicrobial Agents and Chemotherapy, 49(6), 2474-2478. http://dx.doi.org/10.1128/ AAC.49.6.2474-2478.2005. PMid:15917549.

Vilela, C., Moreirinha, C., Domingues, E. M., Figueiredo, F. M., Almeida, A., \& Freire, C. S. (2019). Antimicrobial and conductive nanocellulose-based films for active and intelligent food packaging. Nanomaterials, 9(7), 980. http://dx.doi.org/10.3390/nano9070980. PMid:31284559.

Wei, P., Cao, J., Shen, X., \& Li, C. J. (2019). The preservation effect and mechanism of gelatin on golden pompano (Trachinotus blochii) fillets during cold storage. Food Science and Technology, 39(Suppl. 2), 626-631. http://dx.doi.org/10.1590/fst.28718.

Zulkarneev, E. R., Aleshkin, A. V., Kiseleva, I. A., Rubalsky, E. O., \& Rubalsky, O. V. (2019). Bacteriophage cocktail effectively prolonging the shelf-life of chilled fish. Bulletin of Experimental Biology and Medicine, 167(6), 818-822. http://dx.doi.org/10.1007/s10517-01904630-w. PMid:31656009. 